\section{Central North Carolina}

A well attended meeting was held on 18 November 1982 at the National Center for Health Statistics, Research Triangle Park, N.C. At a short business meeting conducted by Chairman Larry Lee, Mike Modrick was appointed chairman of a committee to recommend a position for the chapter to take on the AMS Seal of Approval. Other committee members were Larry Lee, Art Dodd, and Greg Feshel.

Orrin Pilkey, of the Department of Geology at Duke University, Durham, N.C., was the speaker for the evening. His subject was, "The Greenhouse Effect, Sea-Level Rise, and Shoreline Erosion." Pilkey presented tide gage evidence gleaned from 44 world wide gages and other data, indicating a rise in ocean levels of about one foot per century. There has been a significant acceleration of this rise as the world has become more industrialized, which Pilkey attributes to the greenhouse effect. A four foot rise, plus or minus two feet, is expected by the year 2100 . With the presentation of excellent slides illustrating coastal changes in recent years, Pilkey was able to show how man usually destroys the natural coastal system when he tries to protect beaches, buildings, channels, and lighthouses.-John R. McClain, Secy.

\section{District of Columbia}

The first meeting of the 1982-83 season was held at the Goddard Space Flight Center, Greenbelt, Md., on Wednesday, 15 September. Chairman Owen Thompson introduced the new officers to about 100 people attending. The guest speaker, J. Murray Mitchell, Jr., Science Advisor to the Environmental Data and Information Service (EDIS) of the National Oceanic and Atmospheric Administration (NOAA), spoke on 'Recent Trends of Global Temperature: A Tug-of-War between Volcanoes and Carbon Dioxide."

He related that the average temperature of the Northern Hemisphere has risen, fallen, then risen again in the past century. A good case can be made for ascribing the bulk of these past changes to volcanic eruptions. But, an underlying warming trend from the $\mathrm{CO}_{2}$ greenhouse effect may already have begun. This warming will be offset in the future only if the pace of volcanic activity steps up considerably, or if the sun should happen to cool in the course of a long-term activity cycle.

Following the meeting, Vice Chairman Albert Arking of the National Aeronautics and Space Administration (NASA)/ Goddard Laboratory for Atmospheric Sciences (GLAS), conducted the group through a demonstration of the NASA Atmospheric and Oceanic Information Processing System (AOIPS).

The second meeting of the season was held on Wednesday, 20 October at the World Weather Building, Camp Springs, Md.

${ }^{1}$ Meeting reports received at headquarters before 17 September are included. Copy from chapter representatives should be typed double-spaced and submitted to the News Editor in duplicate.-News Ed.
The guest speaker was Professor Emeritus Helmut Landsberg from the University of Maryland. His topic was, "Knowledge and Uncertainities in the Relations of Weather to Health."

Landsberg is widely regarded as a leading expert on weather effects on human health. In his long and distinguished career, he has held many professional offices, including President of the American Institute of Medical Climatology, and won coveted awards and prizes for his research in biometeorology and bioclimatology. He is the author of nearly 400 articles, monographs, and reviews covering an enormous range of subjects, including the widely read book Weather and Health.

It has long been known that weather has important effects on human health and well being, explained Landsberg. Certain effects of weather on human health and disease, including those on carriers of disease, are well documented. The important information of weather-related drug action is just emerging. The behavioral and psychological effects of weather still need much further exploration. In this lecture, Landsberg reviewwed our knowledge and our uncertainities of these interactions.-Arthur R. Thomas, Recording Secy.

\section{El Paso-Las Cruces}

The 5 October meeting of the chapter was held at noontime at the White Sands Missile Range Officers Club. President Stu Bowersox welcomed everyone and solicited judges for science fairs to be held during the coming year. After Gary McWilliams read the minutes of the last meeting, Doug Copp introduced the featured speaker, David Hathaway, an astrophysicist at the Sacramento Peak Observatory. Hathaway gave a brief history of the observatory, discussed its major functions, and presented some data gathered on the El Chichon volcanic ash cloud.

The Sacramento Peak Observatory is located at an elevation just over $9000 \mathrm{ft}$ in the Sacramento Mountains of South Central New Mexico. The observatory was founded in 1951 by the Air Force Geophysics Laboratory to predict solar flares and their effect on the ionosphere. In 1976, the National Science Foundation assumed operation of the observatory. Today, the observatory employs approximately 70 people, and one of its major research areas is the study of the dynamics of solar convection zones. These convection zones appear on the surface of the sun as granules, and vary in size. For instance, there are mesogranules which are $30000 \mathrm{~km}$ across, and there are macrogranules which are $60000 \mathrm{~km}$ across. Study of the sun's magnetic field provides information on the circulation patterns of these convective zones.

Before discussing the El Chichon Volcano, Hathaway briefly discussed the Solar Maximum Satellite Experiment. This experiment more accurately quantified the value of the solar constant and determined how much the solar constant drops with increased sunspot activity. The solar constant was found to drop between one and several tenths of a percent during periods of high sunspot activity.

The El Chichon Volcano erupted 4 April 1982 in Mexico, jetting an estimated 10 million tons of dust into the atmosphere, which is about 20 times the amount of dust that Mt. 
St. Helens put into the atmosphere. More importantly, the El Chichon Volcano was responsible for putting a much larger quantity of sulfur dioxide and sulfuric acid into the upper atmosphere than the Mt. St. Helens Volcano. Sulfur dioxide and sulfuric acid can form aerosols having diameters very effective for scattering light in the visual range. The El Chichon Volcanic ash cloud has been identified as far south as the Equator and as far north as $40^{\circ} \mathrm{N}$. It is believed that the ash cloud will spread over the entire Northern Hemisphere in a few months. The height of the ash cloud, between 15 and $37 \mathrm{~km}$, has made it difficult for aircraft such as the U-2, which can only fly to altitudes of about $22 \mathrm{~km}$, to make measurements of the cloud. Consequently, balloon-borne instrumentation are being used to make measurements in the cloud.

Hathaway further stated that during a one-week period in May, observatory measurements indicated that the cloud was responsible for reducing the sun's direct intensity by $30-40 \%$. During May and June, measurements indicated a 5\% reduction in incident radiation. It has been estimated that the ash cloud could cause a $0.5^{\circ} \mathrm{C}$ cooling in the Northern Hemisphere during the coming year. One possible consequence of this cooling is a change in the large scale circulation pattern of the Northern Hemisphere.

A brief question and answer period followed Hathaway's talk.-Gary McWilliams, Secy.-Treas.

\section{Farthest North}

Staff Sargeant Dennis Weatherford discussed the weather and climate of Florida at the 21 October meeting. Weatherford is with Detachment 2, 11th Weather Squadron, Eielson Air Force Base, just southeast of Fairbanks, Alaska.

Weatherford pointed out that differences exist between the climate of the northernmost section of Florida and the climate found over the peninsular part of the state, to the south. The northernmost section of the state is occasionally subject to cool air intrusions from the north during the winter. Over the peninsular part of the state, where marine influences dominate, such cooling events occur less frequently. Often in the winter, cold fronts will stall after passing the northernmost part of the state. In such cases the northern part of the state will have considerable stratiform cloudiness, while sunny skies prevail to the south. Often, the stalled fronts eventually drift back northward as warm fronts.

The important dynamic mechanisms for enhancing convection in Florida were pointed out by Weatherford. Outflow boundaries, the sea breeze, frontal boundaries, and lake effects can all serve to intensify convective activity. He said that although Florida thunderstorms produce a great deal of lightning, there is not much hail or tornadic activity. He cited a lack of vigorous large-scale dynamics as a major factor in inhibiting severe weather. Also, much of the hail produced in Florida thunderstorms melts before it reaches the ground, since freezing levels are often between 12000 and $15000 \mathrm{ft}$.

Weatherford also discussed the importance of easterly waves as breeding grounds for hurricanes. He felt the biggest problem in forecasting easterly waves, where satellite data is so important, was the lack of data, especially ship reports. Weatherford discussed some of his experiences in hurricane forecasting, pointing out that the greatest destruction associated with hurricanes is not due to wind damage, but is instead due to the surge of water inland.

He also compared and contrasted the climate of Florida with that of the Fairbanks area. Among other differences, he noted that although the relative humidities for the two areas are often comparable, the actual water vapor content of the air

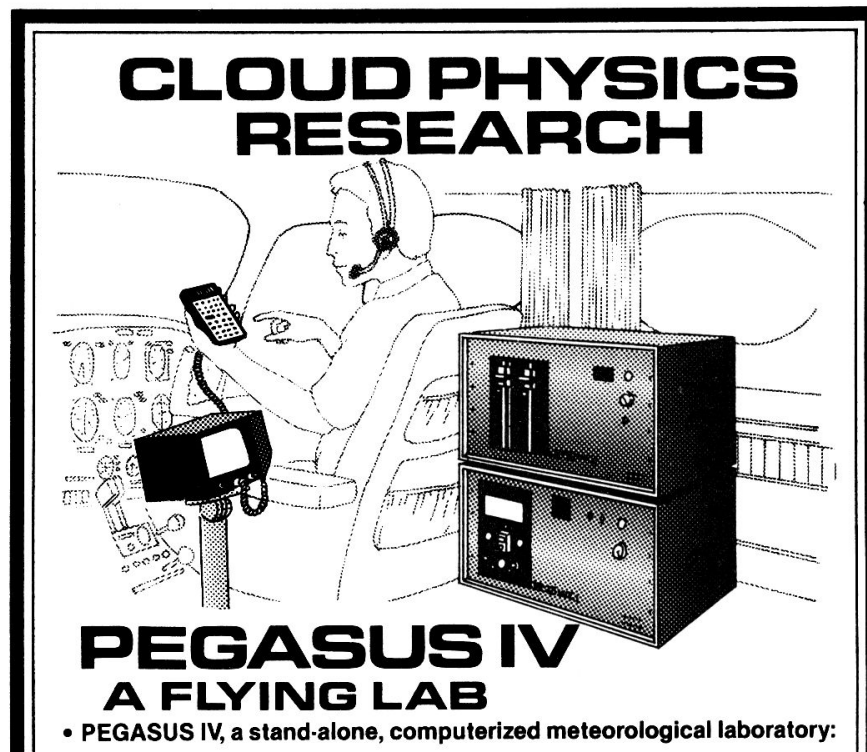

- Only connections required are to aircraft's pitot and power supply.

- Self-contained flight and cloud physics sensors.

- Standard bus architecture, Z80A CPU and CP/M ${ }^{\circledast}$ operating system.

- Data storage on two standard 8 " disk drives.

- Built for meteorological application but capable of much more.

- Tolal hardware and software support.

- CALL OR WRITE FOR ADDITIONAL INFORMATION.

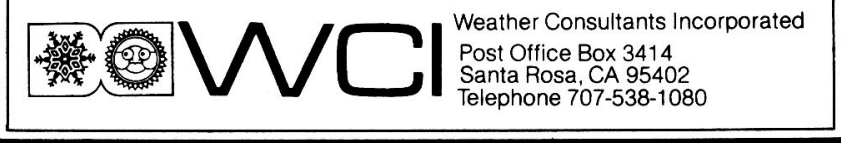

can be $8-10$ times higher in Florida.-Doug Botner, Secy.-Treas.

\section{Florida State University (Student)}

The first meeting of the 1982-83 year was held 24 September. After the officers were introduced, Treasurer Jesse Moore announced that dues were two dollars per semester, and Jon E. Ahlquist was introduced as the faculty sponsor. President Randy Decker discussed possible chapter activities such as a field trip to the airport weather office, and guest speakers; and Joe Higginbotham announced the National Forecasting Contest.

Jesse J. Stephens, Chairperson of the Florida State University Meteorology Department, gave a tour of the department and introduced the professors. He also mentioned that if there was a demand for learning the McIDAS system, a class would be arranged. After the tour, Thomas A. Gleeson was announced as student/faculty ombudsman, and Charles Paxton was elected to fill vacant secretary position.

On 26 October, about 35 members toured the National Weather Service Office at the Tallahassee Regional Airport. There was no formal meeting.-Charles Paxton, Secy. 


\section{Greater Kansas City}

The Hereford House was the site of the 3 November 1982 meeting, which was attended by 28 members and guests.

David Dilley, the evaluations officer from the National Weather Service Forecast Office, Boston, gave a talk entitled "The Great Northeastern Blizzard of 1978." This storm, which occured from 5-7 February, caused 99 fatalities, and left 39,389 people looking for shelter. Boston received 27 in. of snow, including a record 23.6 in. in $24 \mathrm{~h}$. During the storm, winds gusted to $92 \mathrm{mph}$ at Chatham, Mass. A record tide was reported at Portland, Maine, while at Boston, tides were $5.1 \mathrm{ft}$ above normal.

The storm itself developed in the classic manner. A Gulf of Mexico storm induced a secondary (Hatteras) low which intensified while it moved up the coast. The storm stalled southeast of New York City and looped across its own track before heading out into the North Atlantic. At $500 \mathrm{mb}$, a large, negatively tilted trough was associated with the storm.

The LFM model from the National Meteorological Center (NMC) provided the forecasters with excellent guidance. The model, run using 12 GMT data from 5 November, indicated the development of a storm which would affect the coast within $12 \mathrm{~h}$. Further, the $48 \mathrm{~h}$ numerical prognosis indicated that the low would still be effecting New England.

Based upon the model output, the New York City forecast office issued a winter storm watch $17 \mathrm{~h}$ prior to the development of the surface low. Boston followed with a watch $12 \mathrm{~h}$ later (still before the cyclogenesis). This storm was a case in which the system worked almost flawlessly.-Joseph $T$. Schaefer, Secy.-Treas.

\section{Interior of Eastern New York}

The second meeting, of the year, was held on 27 October 1982 at the Channel 13 television studios in Mennands, N.Y. The 35 members and guests in attendance listened to talks given by Todd Gross, TV 13 meteorologist, and Richard E. Orville, State University of New York at Albany (SUNYA) professor.

Gross opened the evening with a presentation on peak autumn foliage color, noting that the trees in higher elevations peak in color earlier than trees in lower elevations. Through his own observation, he determined that peak color was reached on 1 October in the hills of central Rensselaer county, located due east of Albany with an elevation of $1500 \mathrm{ft}$ above sea level. The capital district, $250 \mathrm{ft}$ above sea level, reached peak color on 14 October.

Richard Orville followed Gross with a presentation of the East Coast Lightning Detection Network, which presently consists of nine locations with directional finders (DFs). Five DFs are in New York, two in Maryland, one in Pennsylvania, and one in Virginia. The lightning detection system headquarters, located in the Earth Science Building at SUNYA, allows real time map displays of lightning ground strikes within the coverage of the lightning detection network. The ground strike locations, time of occurence, peak strike currents, polarities, and other physical characteristics of the lightning flashes are stored for future research. Orville showed the usefulness of the system by presenting his results from the 8 October 1982 thunderstorm that hit the Albany area, and areas east, to the Atlantic coast. The system recorded a total of 11714 flashes during the storm's life, the second highest flash total for a thunderstorm event detected since the system became operational in March 1981. During the peak of the storm, between $10 \mathrm{pm}$ and $11 \mathrm{pm}$ EDT, 1750 flashes were recorded (about one flash every two seconds), which was the highest hourly rate ever recorded by the system!

Gross concluded the meeting with a tour of the TV 13 news studio, the highlight of which was the newly purchased satellite receiver. Satellite pictures are received from both GOES east and west satellites, and from these, Gross is able to make picture sequences of cloud movements to use for his television forecast presentation.-Paul A. Gluhosky, Secy.-Treas.

\section{Monterey Peninsula}

A joint AMS / Monterey Institute for Research in Astronomy (MIRA) meeting was held 2 October at Monterey Peninsula College. James Pollack, of the National Aeronautics and Space Administration (NASA) Ames Research Center in Sunnyvale, Calif., spoke on planetary atmospheres, beginning with Mercury and proceeding through the solar system. Afterward, he entertained questions which included a discussion on the effects of recent volcanic eruptions upon the Earth's atmosphere.-Patrick Harr, Secy.

\section{New York City}

The chapter held its first meeting of the 1982-1983 season on Thursday, 28 October 1982, at the Eastern Region Headquarters of the National Weather Service (NWS) in Garden City, N.Y. About 25 members and friends attended.

Robert L. Fuller, Vice-Chairperson, opened the meeting and introduced the guest speaker for the evening, Joseph Tabaco, Computer Systems Analyst, ADP Manager, Data Acquisitions Division, NWS Eastern Region Headquarters. Tabaco talked about his earlier career in the military, and as a civilian technician and part-time reservist. During that time, he participated in hurricane, tropical storm, east coast winter storm, and aerial weather reconnaissance flights with the "Typhoon Chasers," "Hurricane Hunters," and "Storm Trackers" units of the U.S. Air Force and Air Force Reserve. His presentation was accompanied by a slide program.

He told stories of the thousands of flights into and through hurricanes, tropical storms and depressions, and east coast winter storms, as well as the weather modification missions and research programs he had participated in. He is currently a part-time Guardsman serving as the Station Chief of the 201st Weather Flight of the New York Air National Guard.

Frequent questions and comments from the group provided for a lively and informative session.-Edwin C. Heidelberger, Secy.

\section{North Texas}

The chapter held its 21 October meeting, attended by 21 people, at the Arlington Center Library. Billie J. Cook, retired from the National Weather Service (NWS), spoke on "A Snow Index Using $200 \mathrm{mb}$ Warm Advection." Cook stated that before forecasting snowfall amounts, the type of precipitation that will fall must first be determined. A simple rule is that the precipitation will be snow if the wet-bulb temperature curve goes below freezing within $2500 \mathrm{ft}$ of the surface and does not go above freezing at a higher level.

The technique he described involves determining the thermal pattern at $200 \mathrm{mb}$. The average snowfall during the fol- 
lowing $24 \mathrm{~h}$ will be about one-half the indicated warm advection, in Celsius degrees, at $200 \mathrm{mb}$. As an example, Cook stated that if the $200 \mathrm{mb}$ temperature at some location is $-60^{\circ} \mathrm{C}$, and the warmest $200 \mathrm{mb}$ temperature upstream is $-45^{\circ} \mathrm{C}$, then the average snowfall will be one-half of $15^{\circ} \mathrm{C}$ or $7.5 \mathrm{in}$. The area of the heaviest snowfall will be near the coldest air at $200 \mathrm{mb}$, that is downstream from the warm pocket.

Cook emphasized that the technique should only be used as a supplement to established forecast practices. The index is not valid where local effects such as lakes and mountains are a factor. A complete description of the technique can be found in the National Oceanic and Atmospheric Administration (NOAA) Technical Memorandum NWS SR-93. Following a discussion period, the meeting was adjourned.-Buddy McIntyre, Secy.-Treas.

\section{Sacramento}

The first meeting of the 1982-83 year was held on 5 October at the Sacramento Municipal Utilities District (SMUD) Training building

In a program entitled "1981-82 Winter Storms in the Sierra Nevada," John James, a consultant, university instructor, and meteorologist for the SMUD program, presented a slide show describing in detail, the storm from 4-5 January 1982 which left record snowfall at Echo Summit. He discussed the development of the severe storm which he believed to be caused by a "convergence" of the polar and the sub-polar jets.

The second meeting of the 1982-83 year, held 2 November, was also at the SMUD Training Building.

Jack Park, an expert in the field of wind power, presented a slide show describing the history of wind power throughout the world. He discussed the different types of wind power generators, explained the lack of "standards" in the wind power industry as a whole, discussed data acquisition systems, and talked about the potential for wind farming on marginal land.-Lyle R. Chinkin, Secy.-Treas.

\section{Twin Cities}

The November meeting, held on the St. Paul Campus of the University of Minnesota on 18 November 1982, was a joint meeting of the AMS and the Upper Midwest Air Pollution Control Association (APCA). Walter Lyons, of Meteorological Applications, Inc., represented the AMS and spoke on the observation and study of "Persistent Elevated Pollution Episodes."

Lyons's talk included a movie that demonstrated the Persistent Elevated Pollution Episodes (PEPE) over large areas of the eastern half of the United States. The pollution cloud is visible from the GOES satellites as hazy gray areas in otherwise cloud free patterns. On the ground, these events reduce visibilities rapidly. Interestingly, embedded within these pollution areas, are clear holes. Lyons postulated that convective action may be responsible for the cleaning of this air. $\mathrm{He}$ is continuing the development of remote sensing techniques to study long range pollution transport.

Speaking for APCA, Perry Sampson, of the University of Michigan, presented his modeling of large scale pollution transport in the Eastern United States. He discussed the present status of a model to connect sources of sulfate pollution to the environmentally sensitive regions of the eastern United States. Based on wind climatology, the model determines the probability that pollution originates within grid areas in the
DOPPLER DOES IT BETTER NOW with the NEW and UNIQUE
"CODED PULSE" Technique

- Measures winds to 1000 meters

- 30 layers including $\sigma_{\theta}$ and $\sigma_{\omega}$

- Powerful PDP/1103 16-bit microcomputer

- Remote phone modem printout

- Leases available

REMEMBER-Do It With Doppler By REMTECH

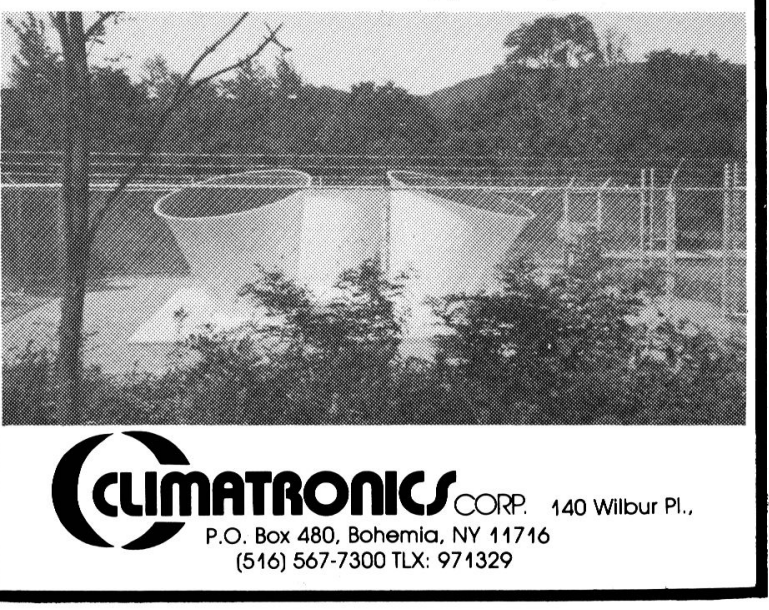

model. Knowing the grid areas' pollutant source strength, the model then determines the relative effect each area of the country has on the pollution observed at the sensitive regions. Sampson also pointed out that because of the complex interactions of the constituent chemicals that produce the pollution cloud, there are limitations to this simple model. - Noel $\mathrm{J}$. Petit, Secy.

\section{Western New York}

The chapter's first meeting of the 1982-83 season was held on 4 November at Maryvale High School in suburban Cheektowaga, N.Y. Lou McNally, staff meteorologist at Buffalo's WIVB-TV (Channel 4), spoke on the role of the weather forecaster in today's media. McNally noted that up until a few years ago, weather in most television markets was relegated to "comic relief," with pretty faces and clowns predominating. There were a few notable exceptions, however, especially in the Boston market where meteorologists have been present on every newscast for a generation, resulting in a more "educated" public in terms of forecasting. With the blossoming of the "consulting" business, however, there has been a tremendous push for the "professional" (i.e., meteorologist) to present the weather in many more markets. Nowhere has this been more evident than here in Buffalo, where two of the three stations now employ meteorologists, whereas none did prior to 1981. McNally, at Channel 4 for eight months now, sees this as a vast opportunity to help educate the public in the vagaries of weather in general, as well as our own unique 
microclimate here. "It won't happen overnight," noted McNally, "it may even take a generation, but it's inevitable."

The 32 members present then participated in a lively question and answer session, questioning things such as the problem of too many different forecasts floating around town, citing Boston as an example. McNally defended the practice though, by stating that the poor forecasters would "fall by the wayside" as the better ones develop increased credibility. He did stress unanimity when serious weather conditions arise, as with National Weather Service (NWS) warnings, etc.

A review of club plans was made by President Ken Remington, and Steven McLaughlin readied the approximately 50 "Snow Spotters" for the coming winter. A "snowfall pool" was also initiated, with the person prediciting the amount closest to the total seasonal snowfall at the Buffalo Airport, winning a prize that has yet to be determined (a snow shovel perhaps?).

Following refreshments, the meeting was then moved to the NWS office at the airport. While the meteorologists there were giving the chapter a tour, interesting weather conditions developed. Conditions seemed to be lining up for our first "lake effect" storm of the season, scheduled to hit the following day, and all had a chance to view these developments first hand: a sharp trough over lakes west of us, colder air moving in, a very warm lake, and a long fetch (SW) up the entire length of the lake. Sure enough, the following day, 5 November, brought an unusually early and strong lake effect storm to metropolitan Buffalo, snarling the area with 3-8 in of heavy, wet snow, with a narrow band near the airport receiving up to a foot. So all members had a chance to view a "classic" lake effect storm in the making.-Stephen F. McLaughlin, Secy.-Treas.

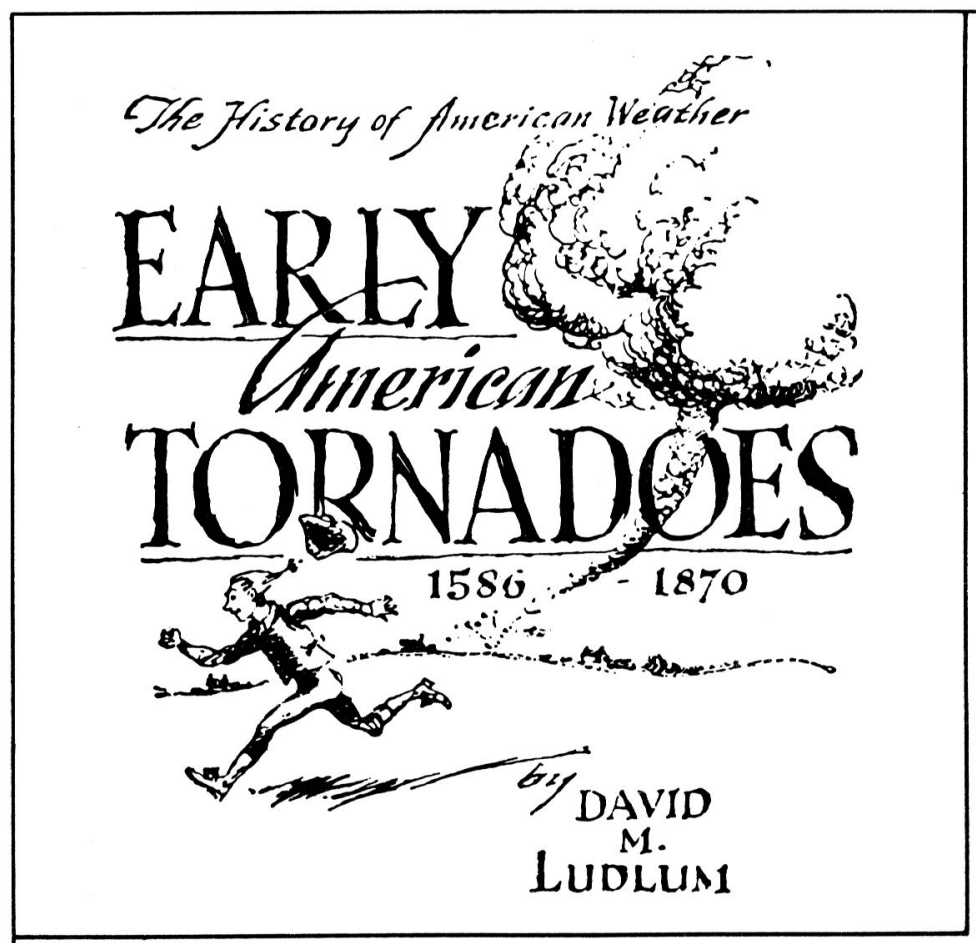

The author of Early American Tornadoes has set down in chronological order and in proper geographical setting the meteorological characteristics of all reported storms of the tornado classification in the United States prior to 1870 and has described the intellectual effort of early American scientists in their attempts to understand tornadoes and like phenomena.

The original accounts of storms, beginning with Roanoke Colony waterspouts in 1586 and 1590 and John Winthrop's "sudden gust" in 1643 , provide interesting first-hand descriptions of storms and also give glimpses of the people who wrote the accounts. Beginning with Cotton Mather and his theological hypothesis of the causes of storms, the author gives us insight into the development of meteorology in America, as it progressed through Benjamin Franklin, Elias Loomis, Lorin Blodget, William Ferrel, James Espy, and William Redfield. The appendix includes a graphic description of a Wisconsin tornado of 1865 (a prize essay from the American Meteorological Journal) and chronological, geographical, and author indexes.

$$
\begin{aligned}
& \text { Nonmembers: Price: \$12.00* } \\
& \text { Members: } \quad \$ 7.00^{*} \\
& 219 \text { pages } \\
& \text { * (add } \$ 2.00 \text { postage/handling) } \\
& \text { Send order and remittance to: }
\end{aligned}
$$

\section{AMERICAN METEOROLOGICAL SOCIETY 45 BEACON ST., BOSTON, MASS. 02108}




\section{THE GR21 MICROLOGGER}

INTELLIGENT ENVIRONMENTAL DATALOGGING

On-site processing compresses more information into each stored data value.

Direct recording of mean wind vector, standard deviation, max and mins, histograms, input products, differences, and many more.

Portable, battery operation (up to six months use on eight $D$ cells).

Seven analog and two pulse counting inputs.

Two binary input and four control output ports.

Data retrieval via the display, cassette tape, CR56 Printer (shown), or telephone interrogation.

Automated network interrogation when mated with the C2000 Central Microcomputer.

Over 1700 in use today; priced at $\$ 1600$.

Write or call for complete technical information.

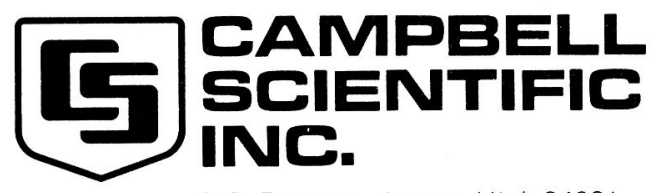

P.O. Box 551 . Logan, Utah 84321 Phone (801) 753-2342

TLX 453058

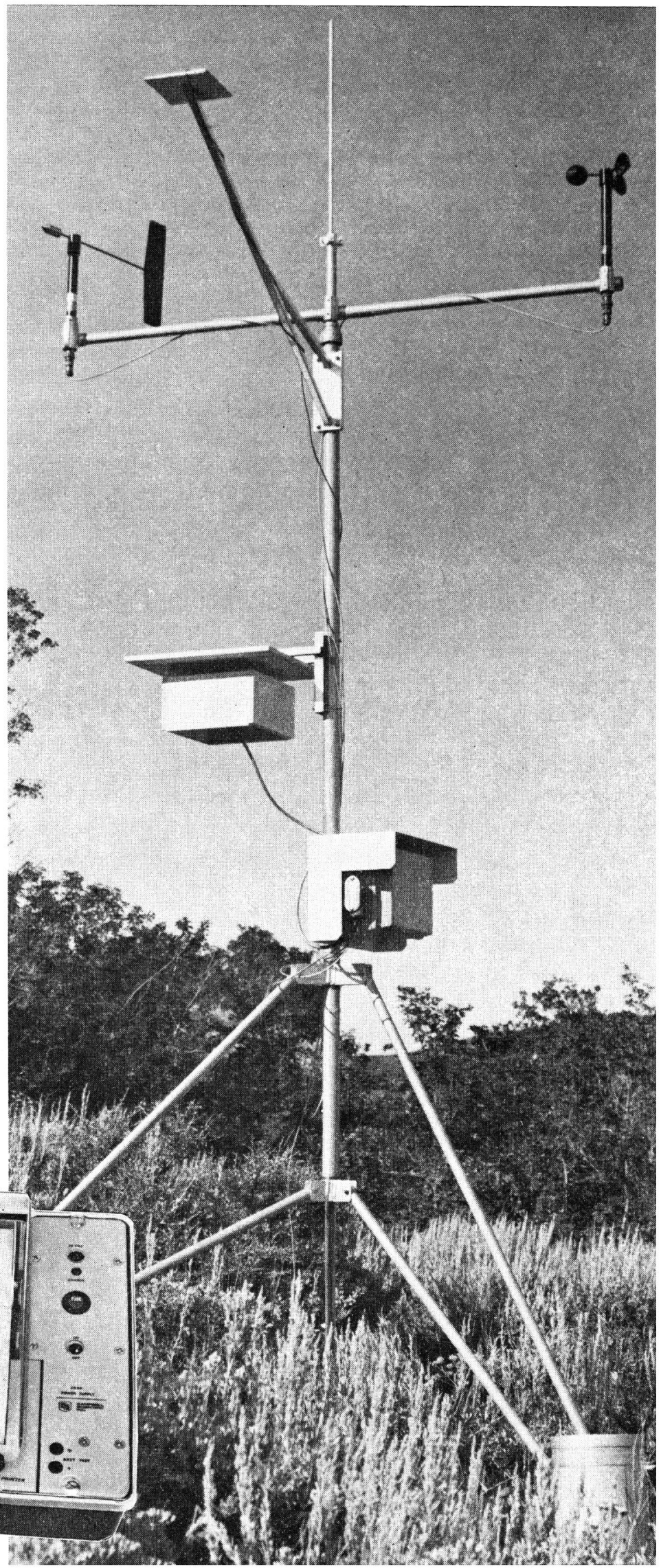

